\title{
IMPROVEMENT OF THE RENTAL PAYMENT SYSTEM FOR SPECIAL USING OF WATER BY MINING ENTERPRISES
}

\section{O. Tverda, T. Hrebeniuk, K. Tkachuk, M. Repin}

National Technical University of Ukraine «Igor Sikorsky Kyiv Polytechnic Institute»

prosp. Peremohy, 37, Kyiv, 03056, Ukraine.

E-mail: tverdaya@ukr.net; t.hrebeniuk07@gmail.com; kkttkk297@gmail.com; rmv.kpi.iee@gmail.com

Purpose. Improvement of the system of rent calculation for special water using by mining enterprises carrying out blasting operations in order to increase the ecological efficiency of both the process of water using and the process of explosive destruction of rocks. Methodology. Generalization of modern achievements on the improvement of the system of charging for water using, drainage and special water using in Ukraine and abroad has been carried out. Regulatory framework of Ukraine on water using and drainage issues has been analyzed. The disadvantages of the system of charging for water using and drainage in Ukraine, and related problems, have been identified. It is proposed to set the rent rate for special water using by mining and processing enterprises based on the consideration of capital costs for the implementation of dust suppression technologies and operating costs to maintain their normal functioning. The costs of possible ways to modernize blasting technology, which involve replacing water using as dust suppressant, have been evaluated. Results. For the first time, with the purpose of rational water using and compliance with the norms of harmful effects on the environment, tariff rates of rent for special water using by mining and processing enterprises, that carry out blasting operations, have been developed. Originality. The dependence of the tariff rates of rent for special water using by mining enterprises for dust suppression on the height of the dust-gas cloud formed during explosion in the quarry has been established. The tariff net of rent rates for special water using by the enterprises of the mining complex is substantiated depending on the technological indicators of blasting and structural and textural features of the rock massifs. Practical value. The proposed approach will motivate mining companies to modernize existing mining technologies to reduce the environmental impact, increase resource conservation, and replenish the budget that can be used to restore water resources in case of misuse. References 10, tables 6, figure 1 .

Key words: rent, water using, dust suppression, mining and processing plant, blasting, tariff rate, quarry.

\section{УДОСКОНАЛЕННЯ СИСТЕМИ НАРАХУВАННЯ РЕНТНОЇ ПЛАТИ ЗА СПЕЦАЛЬНЕ ВИКОРИСТАННЯ ВОДИ ГІРНИЧО-ЗБАГАЧУВАЛЬНИМИ КОМБІНАТАМИ}

\section{О. Я. Тверда, Т. В. Гребенюк, К. К. Ткачук, М. В. Репін}

Національний технічний університет України «Київський політехнічний інститут імені Ігоря Сікорського» просп. Перемоги, 37, м. Київ-56, 03056, Україна.

E-mail: tverdaya@ukr.net; t.hrebeniuk07@gmail.com; kkttkk297@gmail.com; rmv.kpi.iee@gmail.com

Проведено узагальнення сучасних досягнень 3 питань удосконалення системи нарахування плати за водокористування та водовідведення в Україні та закордоном. Проаналізовано нормативно-законодавчу базу України з питань водокористування та водовідведення. Визначено недоліки системи нарахування плати за водокористування та водовідведення в Україні, виявлено пов'язані 3 ними проблеми. Обгрунтовано необхідність удосконалення системи нарахування рентної плати за спеціальне використання води гірничозбагачувальними комбінатами. Запропоновано підхід щодо нарахування рентної плати за спеціальне водокористування гірничозбагачувальними підприємствами, який базується на врахуванні капітальних витрат на впровадження пилеподавлюючих технологій та експлуатаційних витрат на підтримання їх нормального функціонування під час формування рентної ставки. Проведено оцінку вартості можливих шляхів модернізації технології вибухових робіт, яка включає заміну використання води в якості засобу для пилегасіння, як застарілого та нераціонального з точки зору ефективного використання водних ресурсів способу. Уперше 3 метою раціонального використання водних ресурсів та додержання нормативів шкідливих впливів на довкілля розроблено тарифні ставки рентної плати за спеціальне використання води для гірничо-збагачувальних комбінатів, які проводять вибухові роботи. Встановлено залежність розміру тарифних ставок рентної плати за спеціальне використання води гірничими підприємствами для пилеподавлення від висоти пилогазової хмари, утвореної внаслідок проведення масових вибухів на кар'єрі. Обгрунтовано тарифну сітку ставок рентної плати за спеціальне використання води підприємствами гірничопромислового комплексу залежно від технологічних показників вибухових робіт та структурно-текстурних особливостей масивів гірських порід.

Ключові слова: рентна плата, водокористування, пилеподавлення, гірничозбагачувальний комбінат, вибухові роботи, тарифна ставка, кар'єр.

PROBLEM STATEMENT. One of the disadvantages of the system of water using, drainage and special water using in Ukraine is the imperfection of the algorithm of charging. In particular, a number of indicators that affect system performance and the level of resource conservation is not taken into account. The analysis of the international experience of charging for water using has made it possible to systematize and compare the peculiarities and decisions of EU countries and Ukraine in the field of water using (Table 1).

One of the topical solutions offered by overseas practice is to pay for water usage according to the planned volumes for each billing period. It allows the water supply companies to send funds for timely maintenance of the water supply and drainage system, maintain it in good condition at the beginning of the 
billing period, gives information about the expected load on the network. A comparative analysis of the peculiarities of the water using and sewerage system in Europe and Ukraine showed that the algorithm for calculating tariffs for water using and sewage in Ukraine needs improvement. In the process of their

Table 1 - Features of the water management system in Europe and Ukraine [1-3]

\begin{tabular}{|c|c|}
\hline Country & Features of the system \\
\hline Ukraine & $\begin{array}{l}\text { Fee for meters, calculated for each consumer according to the appropriate formulas for cold and hot } \\
\text { water in accordance with regulatory volumes in the absence of a common home accounting device. } \\
\text { There is a rent for special water using. The object of taxation is the actual volume of water. The fee is } \\
\text { charged after water using and drainage. Absence of a permanent cash reserve in the event of accidents } \\
\text { or excessive loads. Tariffs are calculated without taking into account the solvency. There is no planned } \\
\text { volume of water using. }\end{array}$ \\
\hline Germany & $\begin{array}{l}\text { The financial basis of water management system is payments for the water using. Annual payment is } \\
\text { determined for the planning year. Cost estimates are made. Costs of water intake, water receiving and } \\
\text { treating wastewater, maintaining the water level in the water source and other works are defined there. } \\
\text { Costs are calculated in such a way that these contributions could provide such work as: regulation of } \\
\text { the water flow and floods; maintaining surface water levels, supplying water to the public and } \\
\text { industry; sewage disposal; elimination of consequences of wastewater discharge. Some utilities are } \\
\text { private. }\end{array}$ \\
\hline France & $\begin{array}{l}\text { Water usage fee, which is used for improving the status of water resources, and fee for disruption of } \\
\text { water quality. Municipalities are responsible for water supply. City Hall is responsible for tariffs, } \\
\text { quality of services and compliance with standards. The fee is determined by the formula: } \mathrm{Y}=\mathrm{ax}+\mathrm{b} \text {, } \\
\text { where } \mathrm{Y} \text { - fee, which is determined by the average cost of water, considering provided by the billing } \\
\text { system allowances to the base price; } \mathrm{x} \text { - volume of used water; a - the cost of } 1 \text { cubic meter of water; } \\
\mathrm{b} \text { - subscription fee, which is charged even in the absence of water intake. }\end{array}$ \\
\hline Netherlands & $\begin{array}{l}\text { The system of paid water using is based on the principle of full cost recovery for water management } \\
\text { measures. The tax rate varies with the population of the territory and its geographical features. Each } \\
\text { Water Management (out of 12) sets its own tariff, which is calculated based on the volume of } \\
\text { wastewater, the cost of } \\
\text { water purification and managing the quality of water resources. The province may limit groundwater } \\
\text { abstraction. There is a combined sewer system for sewage and storm water. }\end{array}$ \\
\hline $\begin{array}{l}\text { United } \\
\text { Kingdom }\end{array}$ & $\begin{array}{l}\text { Water abstraction and wastewater discharge payments are differentiated by the regions. All water and } \\
\text { sewerage companies are private. The control over the activity of enterprises is ensured through state } \\
\text { licensing. Control over the fulfillment of obligations to provide consumers with water is entrusted to } \\
\text { the Drinking Water Inspectorate. }\end{array}$ \\
\hline
\end{tabular}

A system of paid water using, based on the principle of full cost recovery for water management measures, is especially appropriate for Ukraine from an environmental point of view. For the special water using in Ukraine the rent is paid, but the list of activities, during which the special water using is free, is defined. In particular, rent for special water using is not charged for water used for damping in mines and quarries [3]. This situation leads to uncontrolled and excessive water using by mining companies, does not completely stimulate them to modernize technological lines, in particular, to reduce dust and harmful gases during blasting, to resource conservation. In addition, water performs the function of dust suppression, and the issue of harmful gas emissions and the loss of minerals in the form of excessive volumes of dust fractions remains open. The need to improve the system of rent payment for the special water using by mining and processing enterprises is an urgent, scientific and practical task.

Work goal - improvement of the system of rent calculation for special water using by mining enterprises, which carry out blasting operations, in order to increase the ecological efficiency of both the process of water using and the process of explosive destruction of rocks. determination, the level of solvency of users, geographical features of each territory, costs of water intake, sewage treatment, maintenance of water level in a water source and other types of works should be taken into account.
MATERIAL AND RESULTS. Mining enterprises have a significant impact on the environment, groundwater and surface water. One of the causes of such pollution is the dusting of the waste heaps, the blasting, as well as the process of transportation and processing of the rocks. To reduce the effects of dusting, dust suppression is used, which uses a large amount of water resources for which rent is not provided. Thus, despite pollution of the environment, surface and groundwater, mining companies use large volumes of water for free, which is unacceptable from the point of view of the country's resource conservation and economy.

During mining operations, a significant amount of harmful gases also enters the air environment. The emissions of harmful substances contain chemical substances, that are part of rocks, and substances, released during the explosive destruction of rocks and during operation of machines and mechanisms used in the technology of crushed stone production. The emission of these harmful substances leads to the gradual degradation of the plantations, their decrease in productivity and loss of stability. Under the influence of "foreign" substances for living organisms the ultramicroscopic structure of the cells of plant 
organisms is disrupted, the intensity of growth and productive reactions slows down, the life expectancy of organisms is reduced, aging processes are accelerating [4]. The magnitude of dust pollution is evidenced by the fact that the concentration of dust near sources of formation can range from $0,5 \mathrm{mg} / \mathrm{m}^{3}$ to $3000 \mathrm{mg} / \mathrm{m}^{3}$ and more. The concentration of harmful gases may exceed the maximum permissible concentration by 10 times or more. The largest source of dust and gas pollution is mass explosions. The effectiveness of the following technological processes depends on the results of the explosion [5].

Payment system for special water using should be a tool to stimulate the introduction of resource-saving technologies by enterprises in the fields of extraction, transportation, mineral processing and other fields related to environmental pollution. Premising that the purpose is to encourage large pollutant companies to modernize their technologies and equipment, the rental rate for special water using should be determined based on the capital cost of implementing new technologies and operating costs to maintain their normal functioning. The cost of possible upgrades should also be assessed, for example, alternative methods of dust reducing, replacing the using of water as a dust suppressant.

An analysis of the literature revealed that a significant number of technological and engineering measures have been developed to reduce dust emissions during mass explosions (Table 2) [5,6]. Reducing the level of environmental hazard at opencast mining enterprises can be achieved by the using of neutralizers and catalytically active substances as additives to explosives of an inorganic and organic nature, the transition to non-TNT and low-saltpeter explosives, replacement of charge structures, development of special devices that will reduce seismic load in the quarry area [7].

Table 2 - Main technological and engineering measures aimed at reducing dust emissions during mass explosions [6]

\begin{tabular}{|c|c|}
\hline Measures & Effectiveness \\
\hline The explosion of high ledges & It helps to reduce the dust and gas cloud by 1,3 times \\
\hline Explosion on ungathered rock mass & $\begin{array}{l}\text { The secondary dust and gas cloud is shrinking or not forming at } \\
\text { all (absence of dust from the collapse side) }\end{array}$ \\
\hline Using of borehole hydroplug & $\begin{array}{l}\text { Dust reduction in the dust and gas cloud by } 30-80 \% \text { and } \\
\text { reducing the amount of Nitrogen (II) oxide and Nitrogen (IV) } \\
\text { oxide by } 1,5-2 \text { times }\end{array}$ \\
\hline Use of snow and ice borehole plug in winter & Dust is reduced by $5-10$ times \\
\hline $\begin{array}{l}\text { Applying a layer of artificial snow to the } \\
\text { blasting block and the surrounding area }\end{array}$ & It allows to reduce dust in the atmosphere by $3-5$ times \\
\hline Creating a water mist & $30 \%$ dust suppression \\
\hline Application of hydrogel & $\begin{array}{c}\text { Using of hydrogel borehole plug 2-4 m high contributes to } 34-54 \\
\% \text { dust suppression }\end{array}$ \\
\hline $\begin{array}{l}\text { Irrigation of the blasted block by water-air-jets } \\
\text { created by the jet equipment }\end{array}$ & $\begin{array}{c}\text { Suppression of dust in the quarry during the explosion reaches } \\
70-80 \% \text {, prevents lifting dust from ledges by } 25-40 \%\end{array}$ \\
\hline The use of water solutions of surfactants & $\begin{array}{c}\text { The dust suppression effect reaches } 80-99 \% \text {, reducing the } \\
\text { amount of nitrogen oxides is up to } 28-40 \%\end{array}$ \\
\hline
\end{tabular}

From the analysis of measures, which are given in Table 2 and aimed at reducing dust emissions, the following have been established. Most of them are related to water using, so in the future, preference will be given to the methods that least require water for their implementation. These include the explosion of high ledges, explosion on ungathered rock mass, using of borehole hydroplug, application of hydrogel and the use of water solutions of surfactants. It is decided not to consider the rest of the methods hereafter, as they are quite costly in terms of water using or tied to the cold season.

The cheapest methods, without the use of additional reagents, are the explosion on ungathered rock mass, the explosion of high ledges and the using of borehole hydroplug. However, their implementation requires certain geographical, geophysical and technical conditions within the enterprise. The most versatile, easy to use, method for reducing dust emissions, according to the results of the analysis, is the use of surfactants. As a surfactant for dust suppression is selected dust reagent "Lexol", because it has high efficiency compared to its analogues, has a competitive cost and favorable production conditions in Ukraine [8].

The reagent is an aqueous solution of glycerol tar of vegetable origin, intended for fixing erosion-hazardous surfaces of the poly-mineral composition, which emit dust. Reagent contributes to dust control due to its binding and hygroscopic properties. It is proved that the efficiency of using an aqueous solution of reagent "Lexol" for dust suppression on the rock heaps on average $30 \%$ higher than the use of pure water [8].

In [6], the calculation of pollutant emissions into the atmosphere during mass explosions in quarries was carried out, its results are given in Table 3. 
Table 3 - Emissions of pollutants during mass explosions [6]

\begin{tabular}{|c|c|c|c|}
\hline Pollutant & $\begin{array}{c}\text { Concentration of a pollutant } \\
\text { in a dust-gas cloud, } \mathrm{mg} / \mathrm{m}^{3}\end{array}$ & $\begin{array}{c}\text { Maximum permissible } \\
\text { concentration, } \mathrm{mg} / \mathrm{m}^{3}\end{array}$ & $\begin{array}{c}\text { Annual emission of } \\
\text { pollutants, } \mathrm{t} / \mathrm{year}\end{array}$ \\
\hline Suspended substances & 2562,2 & $0,15-0,5$ & 7715 \\
\hline Carbon monoxide & 564,41 & 30 & 1699,4 \\
\hline Nitrogen oxides & 37,4 & 5 & 112,58 \\
\hline
\end{tabular}

For environmental pollution businesses are required to pay an environmental tax. Let's calculate the amount of environmental tax for air pollution in the absence of environmental measures (for 1 year) according to the data given in Table 3:

$$
\begin{gathered}
\mathrm{T}=7715 \cdot 92,37+1699,4 \cdot 92,37+112,58 \cdot 2451,84= \\
=1145636,28 \text { UAH. }
\end{gathered}
$$

Calculation of environmental tax, provided that explosion of high ledges is used and reduces the dustgas cloud by $29 \%$ :

$$
\begin{gathered}
\mathrm{T}=5446,5 \cdot 92,37+1199,6 \cdot 92,37+79,8 \cdot 2451,84= \\
=809557,08 \mathrm{UAH} .
\end{gathered}
$$

Calculation of environmental tax, provided that borehole hydroplug is used. Dust suppression is assumed to be $50 \%$ and $50 \%$ similar to nitrogen oxides:

$$
\begin{gathered}
\mathrm{T}=3857,5 \cdot 92,37+1699,4 \cdot 92,37+56,29 \cdot 2451,84= \\
=651304,93 \mathrm{UAH} .
\end{gathered}
$$

Calculation of environmental tax, provided that surfactants are used, dust suppression efficiency is on average $95 \%$ and nitrogen oxide emission reduction is $30 \%$ :

$$
\begin{gathered}
\mathrm{T}=385,75 \cdot 92,37+1699,4 \cdot 92,37+78,8 \cdot 2451,84= \\
=385810,30 \mathrm{UAH} .
\end{gathered}
$$

The cost of the above measures varies over a fairly wide range, as is their effectiveness and the effects on the dust-gas cloud. The average annual costs of dust reduction measures are shown in Table 4.

Table 4-Annual cost of dust suppression measures

\begin{tabular}{|c|c|}
\hline Measures & Cost of the measure, thousand UAH \\
\hline The explosion of high ledges & 246 \\
\hline The using of borehole hydroplug & 341 \\
\hline The using of surfactants & 574 \\
\hline
\end{tabular}

According to the results of the above calculations and the data of the Table 4, we will calculate the annual ecological and economic effect from the implementation of the measures under consideration:

$$
\mathrm{E}_{\mathrm{T} 1}=1145636,28+336079,2-246000=1235715,46,
$$

$$
\begin{aligned}
& \mathrm{E}_{\mathrm{T} 2}=1145636,28+494331,35-341000=1298967,63, \\
& \mathrm{E}_{\mathrm{T} 3}=1145636,28+759825,98-574000=1331462,26 .
\end{aligned}
$$

The results of the calculations for each method of dust suppression, the costs of their implementation and the efficiency of dust suppression are given in Table 5 .

Table 5 - Results of calculations of ecological and economic efficiency of dust suppression measures implementation

\begin{tabular}{|c|c|c|c|}
\hline Dust suppression measures & $\begin{array}{c}\text { Cost of the measure, } \\
\text { thousand UAH }\end{array}$ & $\begin{array}{c}\text { Net annual economic } \\
\text { effect, UAH }\end{array}$ & Dust suppression efficiency, \% \\
\hline $\begin{array}{c}\text { The explosion of high } \\
\text { ledges }\end{array}$ & 246 & 1235715,46 & 29 (only dust) \\
\hline $\begin{array}{c}\text { The using of borehole } \\
\text { hydroplug }\end{array}$ & 341 & 1298967,63 & 50 (dust and nitrogen oxides) \\
\hline The using of surfactants & 574 & 1331462,26 & 95 (dust), 30 (nitrogen oxides) \\
\hline
\end{tabular}

The rental rate for special water using will be calculated based on the incentive to use the dust suppression method with the lowest environmental and economic efficiency, but higher than the use of clean water, with the aim of implementing environmental measures that would reduce not only dust concentration but also harmful gases during blasting on quarries, and would increase the level of resource conservation, including water.

The rent rate should also depend on the magnitude of the dust-gas cloud formed during the blasting. Because the larger it is, the greater negative impact on the environment can be observed. Exceeding limit concentrations can be more than 5000 times, and these are by far not the highest values. This will encourage mining companies to carry out smaller-scale blasting operations. As a consequence, it will reduce pollution levels and cause less damage to the business. To facilitate the calculations, the fee will depend on the height of the dust-gas column formed during the blasting. The height of the dust-gas cloud, in turn, depends on the magnitude of the blasting charge, the characteristics of the well and other indicators.

Based on the results of studies in $[9,10]$, the rate for water using for dust suppression should increase when the height of the dust-gas cloud crosses the 60-meter 
mark in the first 0,5 second after a mass explosion. This is because the highest concentrations of harmful substances are observed just after crossing this limit and depend on the mass of explosive charges. It is proposed to increase the rate by an additional $10 \%$ for every 10 meters of the dust-gas cloud height after crossing the 60 $\mathrm{m}$ limit (Figure 1).
Based on the cost of the cheapest dust suppression method (246000 UAH), the calculation of which was carried out for a mining enterprise with an annual productivity of 263 thousand $\mathrm{m}^{3}$ of rock, estimated water consumption over $1774,8 \mathrm{~m}^{3}$, it is proposed to set a rent rate for water $1,15 \mathrm{UAH}$. The calculation of the costs of environmental measures for dust suppression for $1 \mathrm{~m}^{3}$ of the rock mass is given in Table 6 .

Table 6 - Costs of environmental dust suppression measures

\begin{tabular}{|c|c|c|}
\hline Dust suppression measures & $\begin{array}{c}\text { Cost of the measure, thousand } \\
\text { UAH }\end{array}$ & $\begin{array}{c}\text { The cost of the measure in terms } \\
\text { of } 1 \mathrm{~m}^{3} \text { of rock, UAH }\end{array}$ \\
\hline The using of surfactants & 574 & 2,18 \\
\hline The using of borehole hydroplug & 341 & 1,23 \\
\hline The explosion of high ledges & 246 & 0,93 \\
\hline
\end{tabular}

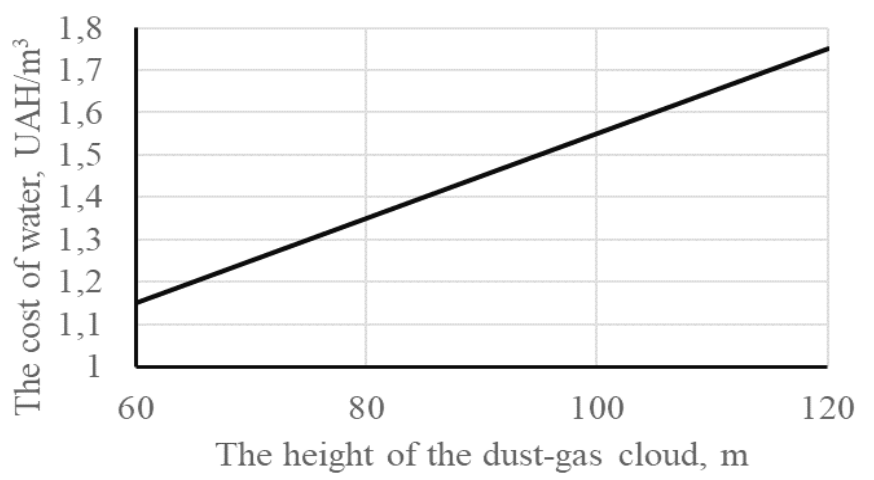

Figure 1 - The dependence of the cost of water for dust suppression on the height of the dust-gas cloud

CONCLUSIONS. 1. Generalization of modern achievements on the improvement of the system of charging for water using, drainage and special water using in Ukraine and abroad has been carried out. Regulatory framework of Ukraine on water using and drainage issues has been analyzed. It is determined that the rent for special water using is not charged for dust suppression in mines and quarries. This situation leads to uncontrolled and excessive use of water by mining companies, does not completely stimulate them to modernize technological lines, in particular, to reduce dust and harmful gases emissions during blasting, to resource conservation.

2. It is proposed to set the rent rate for special water using by mining and processing enterprises based on the consideration of capital costs for the implementation of dust suppression technologies and operating costs to maintain their normal functioning.

3. The costs of possible ways to modernize blasting technology, which involve replacing water using as dust suppressant, has been evaluated.

4. For the first time, with the purpose of rational water using and compliance with the norms of harmful effects on the environment, tariff rates of rent for special water using by mining and processing enterprises, that carry out blasting operations, have been developed. The dependence of the tariff rates of rent for special water using by mining enterprises for dust suppression on the height of the dust-gas cloud formed during explosion in the quarry has been established. Base rent for special use of water by mining enterprises for dust suppression is $1,15 \mathrm{UAH}$.

\section{REFERENCES}

1. Syaska, O. V. (2013), "The analysis of foreign experience in regulating processes of water use and prospects for its application in Ukraine", Ekonomichni nauky. Seriia Ekonomika ta menedzhment [Economic sciences. Series "Economics and Management], iss. 10 (38), pp. 213-224.

2. About approval of the Rules for the provision of centralized water supply and centralized water drainage services and standard contracts for the provision of centralized water supply and centralized water drainage services: resolution of the Cabinet of Ministers of Ukraine, since 05.07.2019, № 690. URL: https://zakon.rada.gov.ua/laws/show/en/690-2019-

\%D0\%BF (accessed: 22.03.2020).

3. Tax Code of Ukraine: Law of Ukraine since 02.12.2010, № 2755-VI. URL: http://zakon.rada.gov.ua/laws/show/2755-17 (accessed: 22.03.2020).

4. Tverda, O. Y., Repin, M. V., Tkachuk, K. K., Radetska, O. Y. (2019), "Ecological and economic efficiency of the resource-saving charge for explosive destruction of rock", Vcheni zapysky TNU imeni V. I. Vernadskogo. Seriia: tekhnichni nauky [Scientific notes of TNU named after VI Vernadsky. Series: technical sciences], volume 30 (69), part 2, № 2, pp. 64-67.

5. Tverda, O., Plyatsuk, L., Repin, M., Tkachuk, K. (2018), "Controlling the process of explosive destruction of rocks in order to minimize dust formation and improve quality of rock mass", Eastern-European Journal of Enterprise Technologies, volume 3, № 10 (93), pp. 35-42. 
6. Zvyagintseva, A. V., Zavyalova, A. Yu. Analysis of the main technological and engineering measures designed to reduce dust and gas emissions during mass explosions at quarries of the mining and processing plant.

URL: file:///C:/Users/User/Downloads/UPLF12e49122f96866 147aeb7208f92a52fb\%20(2).pdf (accessed: 21.03.2020).

7. Kozlovskaja, T. F., Chebenko, V. N. (2010), "Ways of decline of y-level of ecological danger in districts mining by the opened method", Visnyk Kremenchuts'koho natsional'noho universytetu imeni Mykhayla Ostrohrads'koho [Transactions of Kremenchuk Mykhailo Ostrohradskyi National University] issue 6(65), part 1, pp. 163-168.
8. Shchokin, V. P., Nalyvaiko, V. G., Ezhov, V. V. (2018), "Application of Leksol surfactant aqueous solution to bind the dust on quarries' roads and reduce the dust emission during large-scale blasts", Ukrainian Journal of Ecology, issue 8 (1), pp. 755-761.

9. Savotchenko, O. M., Zberovskyi, O. V. (2017), "Research of parameters of dust and gas emissions during blasting operations in quarries", Zbirnyk naukovykh prats $\mathrm{NHU}$ [Collection of scientific works of NHU],№ 51, pp. 218-226.

10. Vorobiev, V. D., Zakharov, V. V., Berezhetsky, A. Ya. (2003), "Reduction of dust and gas emissions during mass explosions in quarries", Bulletin of the NTUU «KPI». Series «Mining», issue 8, pp. 163169.

\section{СОВЕРШЕНСТВОВАНИЕ СИСТЕМЫ НАЧИСЛЕНИЯ РЕНТНОЙ ПЛАТЫ ЗА СПЕЦИАЛЬНОЕ ИСПОЛЬЗОВАНИЕ ВОДЫ ГОРНО-ОБОГАТИТЕЛЬНЫМИ КОМБИНАТАМИ}

\section{О. Я. Твердая, Т. В. Гребенюк, К. К. Ткачук, Н. В. Репин}

Национальный технический университет Украины

«Киевский политехнический институт имени Игоря Сикорского»

просп. Победы, 37, г. Киев-56, 03056, Украина.

E-Mail: tverdaya@ukr.net; t.hrebeniuk07@gmail.com; kkttkk297@gmail.com; rmv.kpi.iee@gmail.com

Проведен анализ современных достижений по вопросам усовершенствования системы начисления платы за водопользование и водоотведение в Украине и за рубежом. Предложен подход по начислению рентной платы за специальное водопользование горно-обогатительными предприятиями, основанный на учете капитальных затрат на внедрение пилеподавляющих технологий и эксплуатационных затрат на поддержание их нормального функционирования при формировании рентной ставки. Впервые с целью рационального использования водных ресурсов и соблюдения нормативов вредных воздействий на окружающую среду разработаны тарифные ставки рентной платы за специальное использование воды для горно-обогатительных комбинатов, которые проводят взрывные работы. Установлена зависимость размера тарифных ставок рентной платы за специальное использование воды горными предприятиями для пылеподавления от высоты пылегазового облака, образованного в результате массового взрыва на карьере.

Ключевые слова: рентная плата, водопользование, пылеподавление, горно-обогатительный комбинат, взрывные работы, тарифная ставка, карьер.

Стаття надійшла 02.04.2020. 